\title{
Class President Election at School as an Example for Democracy Implementations in the Textbooks of German Sachunterricht and Turkish Life Studies
}

\author{
Summary
}

\section{INTRODUCTION}

Having a citizen portrait which has capabilities and values for democratic citizenship for improving the democratic process in the country is one of the most important and maybe even the best reason of the existence of Sachunterricht in Germany and life studies course in Turkey. Activities like electing the class president and experiencing the works of the student council conduce to the children's first experience with democracy. In primary schools, sachunterricht in Germany and the life studies course in Turkey prepare the children for a democratic society in the future by bringing the individuals, who will play a role in the future society, together with the subjects of citizenship education for the first in their life.

\section{METHOD}

Case study research design was used in this study. Case study is a method preferred to be used for understanding the different problems of education, especially for questions related with 'how' and 'why' (Ekiz, 2009: 46). Also with the case study, factors related to the situation (places, individuals, events, processes, etc.) are investigated with a holistic view and it is focused on both how the factors affect the situation and are affected by situation (Yıldırım ve Şimşek, 2008: 77).

\section{Data Collection And Data Analysis}

In this study data were collected by document analysis. The first information source of this study is the subject Class President- Spokeperson for the class, The Election of the Class President and Student Council issues in the unit I, You, We of the textbook Sachunterricht called Jo-Jo, published by Cornelsen Publishing House and used for the 3rd grade students in the state of Niedersachsen, Germany. The second source is the Democracy at School subject which takes place in the My School Excitement theme in the textbook published by Evrensel İletişim Publishing House for life studies course for the 3rd grade students in Turkey. Data were analyzed and compared. Content analysis was applied to the collected data. Data about Class President Elections, the way subject/information is presented, visual proofs and the activity and assessment practices used in the textbooks in Germany and Turkey were analysed.

\section{FINDINGS}

\section{a) Defining of the Candidacy Process}

In the I- You- We unit of textbook of Sachunterricht duties of Class President and election process are being identified and introduced. Students understand the main features of the political campaigns of social life. Then when they examine the subject called Democracy in School in life studies course, they are encountering that what could be the expectations of the class president and promises of president candidates. They do not face with the political terms of the current system. The election process is only explained with the candidateship, in other words, 'the election rights'. This situation raises awareness about the political systems in real life for students. 


\section{b) Defining of the Election Process}

The election process of the textbook of Sachunterricht reflects the features of the democratical elections. The textbook of Sachunterricht gives students a chance to experience a class president election which matches up with a real political election based on terms like general, secret, free, equal and direct. In the life studies course textbook, there is no emphasis about the democratic election process. Besides that, there is no information about the quality of the election process.

\section{c) Student Council}

In the textbook of Sachunterricht the Student Council can be seen as the next step. It can be said that with the participation of the students in the student council, it is aimed to encourage students to participate in local government in their future life. In the life studies textbook there is no emphasis on to the participation in local government.

\section{Textbooks \\ Activities And Evaluation In The Sachunterricht and Life Studies Course}

In the issues being examined in the textbook used in the Sachunterrich evaluation process could be seen in comprehension and apply levels. However, in the life studies course textbook it could be seen in comprehension level.

\section{CONCLUSIONS}

It was found that while the class president election process in the textbook used in the life studies course in Turkey is on comprehension level and without justification, in the textbooks used in Sachunterricht in Germany the class president election process is more encouraging for political participation in their own lives with its candidateship process, democratic election process and student council. Also in the textbook of Germany, the election process is being materialized with photos. Whereas in Turkey, instead of photos, illustrations far away from the reality are used, which makes the process artifical. In the textbook of Germany, how the election process should be made is explained in details, with its conpectional frame and photos. In this point, it can be said that the textbook uses a result process approach. The questions at the end of a topic also encourages the students to practice. It's possible to say that the presentation of the subject could be effective to raise students' awareness to their right to elect and being elected and voting culture. The design of the textbook encourages students to active participation. In the textbook of Turkey, on the other hand, there is no information about how the election should be done with in practice or in comprehension level. In Turkey, the way the textbook presents the election process should be reconstructed. It should be reconstructed so that it involves the whole election process and the active participation of all students. 